\title{
NANOFIBER DEVICES FOR THE TARGETED-DELIVERY OF THERAPEUTICALLY ACTIVE PLANT AND HERBAL INGREDIENTS
}

\author{
Sukhwinder K. Bhullar ${ }^{1,2}$ and Harpal S. Buttar ${ }^{3}$ \\ ${ }^{1}$ Department of Mechanical Engineering, Bursa Technical University, Bursa, Turkey \\ ${ }^{2}$ Department of Mechanical Engineering, University of Victoria, Victoria, B.C., Canada \\ ${ }^{3}$ Department of Pathology and Laboratory Medicine, Faculty of Medicine, University of Ottawa, \\ Ontario, Canada
}

Herbal and plant based remedies have been used since times immemorial for treating illnesses or maladies of variant aetiology, whereas during the past two centuries, the pharmaceutical chemists have discovered many important modern drugs from natural botanicals and microbes. Generally, herbal and plant-derived products containing multiple compounds are administered orally for therapeutic purposes. Currently, targeted drug-delivery systems are being developed and investigated for the treatment of cardio-respiratory disorders, pain relief, wound healing, and life threatening diseases like cancers. A number of novel nanofiber membranes and devices are available for sustained release and to deliver steady supply of natural bioactive ingredients, herbalbased extracts, and a few have been approved by US-FDA and other drug regulatory agencies. The purpose of this mini review is to provide an update on the role of nanofiber devices used for the targeted-delivery of therapeutically active ingredients of plant and herbal origin as well as to underscore the potential for the delivery of cost-effective herbal ingredients and natural plant-based extracts for their biomedical applications in wound healing, inflammation-related diseases and cancer treatment. Biomed Rev 2015; 26: 37-42.

Key words: targeted-delivery, natural botanicals, plant-derived ingredients, nanofibrous medical devices, biodegradable and biocompatible polymers

Received 8 December 2015, revised 17 December 2015, accepted 18 December 2015.

Correspondence to: Dr Harpal S. Buttar, Department of Pathology and Laboratory Medicine, Faculty of Medicine, University of Ottawa, 451 Smyth Rd., Ottawa, Ontario, Canada K1H 8M5 E-mail: hsbuttar@bell.net or drharpalbuttar@gmail.com 


\section{INTRODUCTION}

Herbal and natural botanicals have been used for treating human and animals diseases since ancient time in India, China, Egypt, Europe, Latin-America and Africa. Several investigations in experimental animals and a limited number of clinical observations have revealed that oral administration of herbal and plant products produce favorable results for the treatment of non-communicable diseases such as myocardial infarction and stroke, high blood pressure, type 2 diabetes, obesity, insomnia, chronic inflammatory bowel diseases of unknown origin, osteoarthritis, cancer, and postmenopausal symptoms (see Hassanzadeh et al, this volume of BMR). Also, herbal based medicines have been used for wound and burn care from ancient times to date. For example, curcumin, the therapeutically active component of turmeric shows antiinflammatory, anti-bacterial, and wound healing activities and hastens the healing process and reduces the risk of scar formation (1).

In many cases, however, the underlying mechanisms and validation of biologically active ingredients of plantderived products remain unknown. There is an urgent need of well designed, double-blind, multicentre, clinical trials with adequate number of patients to determine the safety and effectiveness of plant-derived remedies as is done with synthetic pharmaceuticals. Such studies must contain a valid comparator to evaluate the therapeutic potential of herbal and plant products. Mostly, the plant- and food-derived compounds are well-tolerated by the human body, and therefore, their application for the development of alternative therapies may reduce high costs and duration of toxicological studies in drug discovery research, development of new substances, and clinical trials. The plant-based alternative therapies will be highly useful for patients who cannot afford long-term cure with costly synthetic medicines.

\section{THERAPEUTIC POTENTIAL OF HERBALS AND NATURAL BOTANICALS}

The most important data concerning the therapeutic potential of active ingredients of herbals and natural botanicals for the treatment of human diseases has originated from Asian countries, especially India and China. Indian Materia Medica includes about 2,000 medications of natural origin almost all of which are derived from different traditional systems and folklore practices (2). Ayurveda, which literally means the science of life, is one of the oldest system of medicines used in India. More than 25,000 single or poly-herbal formulations are used by the tribal and rural populations in India. But only $6 \%$ of all therapeutically important species, which are noted in ancient literature, have been analyzed phytochemically for their therapeutic potential (3). Many important modern drugs have been discovered from natural botanicals and their molecules have been synthesised and/or modified by the pharmaceutical industry. The development of pharmaceutical chemistry and chemical analyses occurred in the early $19^{\text {th }}$ century onward, and consequently led to the extraction, purification, chemical characterization, and modification of plant-derived extracts and/or ingredients into the synthesis of modern drugs $(4,5)$. Today, herbal medicines in their novel formulations such as nanoparticles, microemulsions, matrix systems, solid dispersions, liposomes, and solid lipid nanoparticles (SLNs), nanomicellar system, nanotubes, and colloidal nanogels have been developed to be used either alone or in combination with other chemotherapeutic agents $(4,6$, 7). The current focus of pharmaceutical researchers is towards design, characterization and development of targeted-drug delivery systems for synthetic drugs, herbal remedies, and plant-derived medicines to enhance their efficacy, tolerability as well as to deliver required quantity of a medicament to targeted diseased area (8-14).

\section{THE DELIVERY OF SYNTHETIC AND PLANT-DERIVED MEDICINES}

The challenges for the systemic delivery of synthetic medicines, herbals and plant-derived products are dissolution and protection of bioactive constitutes in the highly acidic $\mathrm{pH}$ environment of the stomach, absorption of therapeutically active ingredients from the gastrointestinal tract, reduced biotransformation in the gut and liver, and ultimate delivery of the optimum quantity of bioactive substances to reach the circulating blood $(4,15)$. Due to their small size and increased surface area, nano-carriers are being promoted for the delivery of synthetic drugs and herbal remedies to maintain therapeutically required amount of drugs and plant medicines to targeted diseased area as well as to overcome all the obstacles experienced for delivering the optimum quantity at the target site. Sharma et al. have reported (4) several advantages for the delivery of herbal remedies through nano-systems such as: $(i)$ reduction in bulk doses, (ii) delivery at the targeted diseased area for major life threatening diseases, (iii) ease and comfort to patients over the traditional available formulations such as large doses but lesser effectiveness, (iv) ability to deliver high concentrations of drugs to diseased sites due to their unique 
size and high loading capacities and persistence at the sites for the longer periods, $(v)$ enhanced permeation and retention effect, (vi) reduced side effects, and (vii) reduction in the dosage of drug formulations. Considering the significantly successful results obtained with nanomaterials and nanofiber delivery-devices, the US-FDA and other drug regulatory bodies have approved several nanoparticle materials and nanofiber devices for the delivery of synthetic drugs and active herbal ingredients. There is a growing demand for further research to exploit the advantages offered by nanotechnology devices and to enhance their benefits to patients for improving the quality of life. Nanofiber membranes offer unique biomedical potentials for drug incorporation and drug release. Hence, the primary focus of this review is to highlight the biomedical applications of nanofibrous devices for targeted-delivery of cost-effective herbals and plant-derived therapies. The authors have evaluated the most important studies concerning the targeted-delivery of therapeutically active ingredients of plants and herbal remedies.

\section{TARGETED DRUG-DELIVERY SYSTEMS}

Over the past two decades, interest for the biomedical applications of nanomaterials and nanotechnology devices have been growing for the targeted-delivery of synthetic and herbal medicines. The ultrasmall size molecules of nanotechnology materials, in the range of 1-100 nanometers, have unique physiochemical properties and interactions with biological systems, and these characteristics of nanodevices help in exploring the controlled delivery and steady supply of therapeutically active substances to targeted sites (16). For the loading of biologically active materials in nano-fabricated devices, a variety of methods are used to incorporate synthetic drugs and plant-derived products with nanoparticles and nanofibers such as non-woven structures, adsorption, and chemical conjugation. The main advantages of nanoparticlebased drug delivery system are: improvement of plasma or serum solubility of xenobiotics; prolongation of systemic circulation half-life; releasing the bioactive substance at a sustained and controlled manner; and preferentially delivering therapy to the targeted tissues and cells. A number of investigators have reported the usefulness of nanotechnology methods for the concurrent delivery of multiple therapeutic agents to the targeted tissues and cells $(17,18)$. With nanotech devices, the pharmacokinetics and therapeutic efficacy of medicines can be significantly improved in contrast to the conventional drug delivery system, since the drug-loaded nanoparticles can enter host cells and invading microbial organisms easily as well as through endocytosis drug-payloads can be released to treat microbe-induced infections.

It is recognized that the plant-derived medicines are well tolerated by the human body and they produce lesser side effects compared to synthetic pharmaceuticals. Further, the herbals and plant-derived remedies are less costly for shortand long-term cure in comparison with synthetic drugs. Due to the cost-effectiveness, efficacy and safety, awareness of physicians and patients for their curing benefits, the herbal and plant-derived medicines are gaining popularity worldwide, especially in developing countries. The delivery systems for natural botanicals can be fabricated using biomaterials, namely synthetic biocompatible and biodegradable polymers, microlipids, and polysaccharides (19). Such drug delivery methods would help to increase the therapeutic value of herbal remedies for the treatment of chronic diseases like asthma, diabetes mellitus, obesity, cancer, and other life threatening cardiovascular diseases. Examples of delivery systems of herbal medicines, and their biomedical applications are shown in Table 1.

\section{POLYMERIC NANOFIBROUS-WOVEN DRUG DELIVERY SYSTEMS}

Nanofibers of both biopolymers and synthetic polymers have been successfully fabricated (32), which offer high porosity with large surface area-to-volume ratio and are more suitable for cell accommodation, nutrition infiltration, gas exchange and waste excretion (33). Recently, the herbal and plant extracts, powder and nanoparticles intended for biomedical applications have been catching the attention of pharmaceutical researchers. Such therapeutic products are blended with polymers in the form of nano-films or nano-microfibers. Different herbal and plant products are incorporated in nanofibrous-mats with polycaptolactone (PCL) due to their biocompatibility, biodegradability, and substance permeability for wound healing dressings as well as targeted-delivery of medicines and skin tissue engineering. The studies reported in the literature (34-38) are summarized in Table 2.

\section{CONCLUSION}

This review summarizes the most recent developments regarding nanofibers loaded with natural botanical extracts and polymeric herbals and plant products incorporated for targeted-delivery of plant-derived remedies. These nano- and macro-structure promote their candidatures for biomedical 
Table 1. Herbal and plant products delivery systems

\begin{tabular}{|c|c|c|c|c|}
\hline Delivery system & Procedure & Herbal and plant-derived products & Biomedical applications & Ref. \\
\hline $\begin{array}{l}\text { Mouth dissolving } \\
\text { tablets }\end{array}$ & Poly-herbal & & $\begin{array}{l}\text { Effective for lung problems and other } \\
\text { respiratory ailments like asthma, cardiac } \\
\text { distress }\end{array}$ & $(20)$ \\
\hline $\begin{array}{l}\text { Matrix tablets or } \\
\text { multi-particulate } \\
\text { formulations like } \\
\text { microcapsules }\end{array}$ & Granulated herb and a carrier & $\begin{array}{l}\text { Active ingredients from plants consisting } \\
\text { hypericin, hyperforin and chinacosides }\end{array}$ & $\begin{array}{l}\text { Steady supply and sustained release of active } \\
\text { components for targeted drug delivery to cure } \\
\text { diseases }\end{array}$ & $(21)$ \\
\hline Microgranules & $\begin{array}{l}\text { Extrusion-spheronization, fluid } \\
\text { air bed process or a coating- } \\
\text { pan method }\end{array}$ & Gingko biloba & $\begin{array}{l}\text { Particularly to supply mixtures of plant extracts } \\
\text { to cure diseases }\end{array}$ & $(22)$ \\
\hline $\begin{array}{l}\text { Mucoadhesive } \\
\text { system }\end{array}$ & Muco-adhesive polymers & Echinacea, Lavender and Mastic gum & Sustained release for the treatment of diseases & $(23)$ \\
\hline Transdermal films & $\begin{array}{l}\text { Transdermal drug- delivery } \\
\text { system (TDDS) }\end{array}$ & $\begin{array}{l}\text { Boswellic acid (Boswellia serrata) and } \\
\text { curcumin (Curcuma longa) }\end{array}$ & $\begin{array}{l}\text { For continuous administration of medicine } \\
\text { through skin into the systemic circulation } \\
\text { and to circumvent the first-pass metabolism } \\
\text { of the bioactive material, and to avoid pain } \\
\text { associated with injection. Offers drug delivery } \\
\text { with infrequent dosing via zero-order kinetics, } \\
\text { and the therapy can be easily terminated at } \\
\text { any time. }\end{array}$ & $(24)$ \\
\hline $\begin{array}{l}\text { Herbal-based oral } \\
\text { composition for } \\
\text { periodic retention } \\
\text { within the buccal } \\
\text { cavity of a human }\end{array}$ & $\begin{array}{l}\text { Consisting of gels, pastes and } \\
\text { chewing gums. }\end{array}$ & $\begin{array}{l}\text { Radix Polygoni Multiflori, Rhizoma } \\
\text { drynariae, Rhizoma ligustici Chuanxiong, } \\
\text { Calculus bovis, Indigo naturalis, Herba } \\
\text { ecliptae, Pericarpium trichosanthis, Radix } \\
\text { sophorae Flavescentis, Spina gleditsiae, } \\
\text { Radix Angelicae sinensis, Fructus mori } \\
\text { and Halitum. }\end{array}$ & $\begin{array}{l}\text { To reduce loss of scalp hair and to promote hair } \\
\text { growth. }\end{array}$ & $(25)$ \\
\hline $\begin{array}{l}\text { Shuanghuanglian } \\
\text { aerosol (SHLA) }\end{array}$ & \begin{tabular}{|l|} 
Flos Chrysanthemum \\
indicum, Flos Lonicera, Herba \\
houttuynia, Radix Bupleurum \\
and menthene
\end{tabular} & $\begin{array}{l}\text { Flos Lonicera, Fructus forsythia and Radix } \\
\text { scutellaria. }\end{array}$ & $\begin{array}{l}\text { Anti-inflammatory and antiviral effects, a } \\
\text { good curative effect in treating infantile upper } \\
\text { respiratory tract infections. }\end{array}$ & $(27)$ \\
\hline Microparticles & \begin{tabular}{|l|} 
Formulated by different \\
techniques using chitosan, \\
egg albumin, sodium alginate, \\
ethyl cellulose, cellulose \\
acetate, gelatin and beeswax.
\end{tabular} & $\begin{array}{l}\text { Gugulipid extract from the Oleo gum } \\
\text { resin of Commiphora wightii }\end{array}$ & $\begin{array}{l}\text { To reduce the levels of harmful serum lipids in } \\
\text { the blood stream. }\end{array}$ & $(28)$ \\
\hline Microcapsules & $\begin{array}{l}\text { Layer-by-layer adsorption } \\
\text { of carrageenan and } \\
\text { oligochitosan onto calcium } \\
\text { carbonate microparticles with } \\
\text { their subsequent dissolving } \\
\text { after the treatment of EDTA. } \\
\end{array}$ & $\begin{array}{l}\text { Plantain Plantago major and calendula } \\
\text { Calendula officinalis L. (PCE) }\end{array}$ & To accelerates gastric tissue repair. & $(29)$ \\
\hline $\begin{array}{l}\text { Nanoparticles of } \\
\text { TCH (traditional } \\
\text { Chinese herbs) }\end{array}$ & \begin{tabular}{|l|} 
Drying, mincing, extracting, \\
crushing into liquid particles \\
with ultrasonic wave, filtering \\
and nanometerizing into \\
nanoparticles soliquid with \\
nanometer collider. \\
\end{tabular} & $\begin{array}{l}\text { Peach seed, safflower, angelica root, } \\
\text { Szechwan lovage rhizome, Rehmannia } \\
\text { root, red peony root, leech, gadfly, earth } \\
\text { worm and ground beetle, }\end{array}$ & $\begin{array}{l}\text { For quick recovery from arterial embolism and } \\
\text { diminution of thrombi. }\end{array}$ & $(30)$ \\
\hline $\begin{array}{l}\text { Sustained-release } \\
\text { implant }\end{array}$ & Chitosan & danshen (Radix Salvia miltiorrhiza), & $\begin{array}{l}\text { To promote anastomosing and healing on } \\
\text { muscles and tissues at the organic incision site } \\
\text { in abdominal cavities. }\end{array}$ & $(31)$ \\
\hline ArthriBlend-SR & $\begin{array}{l}\text { Formulation containing herbal } \\
\text { extracts and nutrients }\end{array}$ & $\begin{array}{l}\text { Glucosamine sulfate, Boswellin (Boswellia } \\
\text { serrata extract) and Curcumin C3 } \\
\text { Complex (Curcuminoids from Curcuma } \\
\text { longa) }\end{array}$ & \begin{tabular}{|l|} 
To support healthy joints and connective \\
tissues in the body; natural actives for joint care \\
applications; to support the management of \\
inflammatory conditions such as arthritis and the \\
continuous management of symptoms of arthritis
\end{tabular} & $(32)$ \\
\hline
\end{tabular}


Table 2. Herbal products blended with polymers

\begin{tabular}{|c|c|c|c|c|}
\hline $\begin{array}{l}\text { Polymer } \\
\text { (Nanofibers) }\end{array}$ & Solvents & Herbals & Biomedical applications & Ref. \\
\hline PCL/PVP & Chloroform/methanol & Crude bark extract of Tecomella undulata, & $\begin{array}{l}\text { Wound healing and wound } \\
\text { dressing }\end{array}$ & $(33)$ \\
\hline PCL & Chloroform & Aloe vera & Wound dressing applications & (34) \\
\hline Gelatin powder & $\begin{array}{l}\text { Butanol, dichloromethane, } \\
\text { hexane and methanol }\end{array}$ & $\begin{array}{l}\text { Extraction of Centella } \\
\text { asiatica }\end{array}$ & Wound healing ability & $(35)$ \\
\hline PCL & $\begin{array}{l}\text { Dichloromethane (DCM) and N,N- } \\
\text { dimethylforma mide (DMF) }\end{array}$ & Shikonin & $\begin{array}{l}\text { Wound healing and/or } \\
\text { atopic dermatitis }\end{array}$ & $(36)$ \\
\hline PCL & $\begin{array}{l}\text { Chloroform/ } \\
\text { Methanol }\end{array}$ & $\begin{array}{l}\text { Indigofera aspalathoides, } \\
\text { Azadirachta indica, Memecylon edule } \\
\text { (ME) and Myristica andamanica }\end{array}$ & Skin tissue engineering & $(37)$ \\
\hline
\end{tabular}

$\mathrm{PCL}=$ Polycaptolactone $; \mathrm{PVP}=$ Poly-vinylpyrrolidone

applications in treating chronic diseases, including wound, and to reduce cure-cost and improve the quality of life of patients. Further work is needed to improve the fabrication and characterization of polymer-herbal blended nanofibers. Future studies should be done with different biocompatible and biodegradable polymer nanofibers either loaded with crude herbal and plant extracts or their active ingredients to explore the therapeutic benefits and safety using the combination of multidisciplinary approach and interdisciplinary research.

Conflict of interest: the authors declare no conflict of interest.

\section{REFERENCES}

1. Aggarwal BB, Surh YJ, Shishodia S. The Molecular Targets and Therapeutic Uses of Curcumin in Health and Disease. Springer 2007 New York, USA; ISBN13:978-0-387-46400-8: e-ISBN-13:978-0-387-46401-5.

2. Mukherjee PK, Wahile A. Integrated approaches towards drug development from Ayurveda and other Indian system of medicines. J Ethnopharmacol 2005; 103: 25-35, DOI: 10.1016/j.jep.2005.09.024.

3. Narayana DBA, Katayar CK, Brindavanam NB. Original system: search, research or research. Indian Drug Manufacturer's Ass (IDMA) Bull 1998; 29: 413-416.

4. Sharma AT, Mitkare SS, Moon RS. Multicomponent herbal therapy: A review. Int J Pharm Sci Rev Res 2011; 6:185-197.

5. Patwardhan B, Vaidya AD, Chorghade M. Ayurveda and natural products drug discovery. Curr Sci 2004; 86: 789799. DOI: 10.1517/17460441.2.12.1631.
6. Bisht S, Feldmann G, Soni S, Ravi R, Karikar C, Maitra A. Polymeric nanoparticle-encapsulated curcumin ("nanocurcumin"): A novel strategy for human cancer therapy. J Nanobiotechnol 2007; 5:1-18. DOI:10.1186/1477-3155-5-3.

7. Zheng L, Song JF. Curcumin multi-wall carbon nanotubes modified glassy carbon electrode and its electrocatalytic activity towards oxidation of hydrazine. Sens Actuators $B$ Chem. 2009; 135:650-655. DOI:10.1016/j.snb.2008.09.035.

8. Yen FL, Wu TH, Lin GT, Cham TM, Lin CC. Nanoparticles formulation of Cuscutachinensis prevents acetaminopheninduced hepatotoxicity in rats. Food Chem Toxicol 2008; 46:1771-1777. DOI: 10.1016/j.fct.2008.01.021.

9. Zhang JF, Hou SX, Liu HL. Comparison of preparing two polylactide nanoparticles loaded lipophilic anti-cancer herb drug by nanoprecipitation method. Zhongguo Zhong Yao Za Zhi. 2007; 32:303-306.

10. Li Y, Dong L, Jia A, Chang X, Xue H. Preparation and characterization of solid lipid nanoparticles loaded traditional Chinese medicine. Int J Biol Macromol 2006; 38:296-309, DOI:10.1016/j.ijbiomac.2006.03.006

11. Robinson JR. Introduction: semi-solid formulations for oral drug delivery. Bull Tech Gattefosse 1996; 89:11-23.

12. Aungst BJ, Novel formulation strategies for improving oral bioavailability of drugs with poor membrane permeation or presystemic metabolism. J Pharm Sci 1993; 82:979-87, DOI: 10.1002/jps.2600821002.

13. Pouton CW. Formulation of self-emulsifying drug delivery systems. Adv Drug Del Rev 1997; 25:47-58. DOI: 10.1016/S0169-409X(96)00490-5. 
14. Bairwa NK, Sethiya NK, Mishra SH. Protective effect of stem bark of Ceiba pentandra linn. against paracetamolinducedhepatotoxicity in rats. Pharmacognosy Res 2010; 2:26-30. DOI: 10.4103/0974-8490.60584.

15. Zhang L, Gu FX, Chan JM, Wang AZ, Langer RS, Farokhzad OC. Nanoparticles in medicine: therapeutic applications and developments. Clin Pharmacol Ther 2008; 83:761-769. DOI: 10.1038/sj.clpt.6100400.

16. Davis ME, Chen ZG, Shin DM. Nanoparticle therapeutics: an emerging treatment modality for cancer. Nat Rev Drug Disc 2008; 7: 771-782. DOI:10.1038/nrd2614.

17. Peer D, Karp JM, Hong S, Farokhzad OC, Margalit R, Langer R. Nanocarriers as an emerging platform for cancer therapy. Nat Nanotechnol 2007; 2:751-760. DOI:10.1038/ nnano.2007.387.

18. Ansari SH, Islam F, Sameem M. Influence of nanotechnology on herbal drugs: A review. J Adv Pharm Technol Res 2012; 3: 142-146. DOI: 10.4103/22314040.101006.

19. Parakh SR, Gothoskar AV. Review of mouth dissolving tablet technologies. Pharm Technol Advanstar Communications, Duluth, MN, ETATS-UNIS. 2003; 47-52.

20. Blatt Y, Kimmelman E, Cohen D, Rotman A. Microencapsulated and controlled-release herbal formulations. United States Patent 6340478.

21. Marechal D, Yang Wg, Yuzhang H. Sustained-release microgranules containing gingko biloba extract and the process for manufacturing these. United States Patent 7569236.

22. Sterer N, Nuas S, Mizrahi B, Goldenberg C, Weiss EI, Domb A, Oral malodor reduction by a palatal mucoadhesive tablet containing herbal formulation. $J$ Dent 2008; 36:535-539.

23. Verma M, Gupta PK, Varsha BP, Purohit AP. Development of transdermal drug dosage formulation for the antirheumatic ayurvedic medicinal plants. Ancient Sci Life 2007; 1:66-69.

24. Chung H, Burk H, Shu K. Herbal-based oral composition and process of the same. 2001 European Patent EP0862446.

25. Ma B, Duan X, Wang Z. Clinical and experimental study on Shuanghua aerosol in treating infantile upper respiratory tract infection. ZhongguoZhong Xi Yi Jie He Za Zhi 2000; 20:653-655.

26. Tanwar YS, Gupta GD, Ramawa KG. Development and evaluation of microparticles of Gugulipid, The Pharma
Review. Kongposh Publications Pvt. Ltd, 2006; 124-32.

27. Borodina TN, Rumsh LD, Kunizhev SM, Sukhorukov GB, Vorozhtsov GN, Feldman BM. Entrapment of herbal extracts into biodegradable microcapsules. Biochem Suppl Series B Biomed Chem 2008; 2:176-182. DOI:10.1134/ S199075080802008X.

28. Shen YJ, Zhang ZW, Luo XG, Wang XF, Wang HL. Nanoparticles of traditional chinese herbs inhibit thrombosis in vivo. Haematol J 2008; 93:J1457.

29. Zhao HR, Wang K, Zhao Y, Pan LQ. Novel sustainedrelease implant of herb extracts using chitosan. Biomaterials 2002, 23:4459-4462.

30. ArthriBlend SR. A formulation containing herbal extracts and nutrients to support healthy joints and connective tissues in the body. Nutraceut World 2009 http://fi ndarticles.com/particles/mi_hb223/is_6_7/ai_n29102045/

31. Luong-Van E, Grondahl L, Chua KN, Leong KW, Nurcombe $\mathrm{V}$, Cool SM. "Controlled release of heparin from poly $(\varepsilon-$ aprolactone) electrospun fibers," Biomaterials 2006; 27 , 2042-2050. DOI:10.1016/j.biomaterials.2005.10.028.

32. Huang ZM, Zhang YZ, Kotaki M, Ramakrishna S. A review on polymer nanofibers by electrospinning and their applications in nanocomposites, Comp Sci Technol 2003; 63:2223-2253. DOI: 10.1016/S0266-3538(03)00178-7.

33. Jin G, Prabhakaran MP, Kai D, Annamalai SK, Arunachalam KD, Ramakrishna S. Tissue engineered plant extracts as nanofibrous wound dressing. Biomaterials 2013; 724-734. DOI: 10.1016/j.biomaterials.2012.10.026.

34. Suganya S, Senthil Ram T, Lakshmi BS, Giridev VR. Herbal drug incorporated antibacterial nanofibrous mat fabricated by electrospinning: An excellent matrix for wound dressings. J Appl Polymer Sci 2011; 121: 28932899. DOI: 10.1002/app.33915.

35. Sikareepaisan P, Suksamrarn A, Supaphol P. Electrospun gelatin fiber mats containing a herbalCentellaasiatica-extract and release characteristic of asiaticoside. Nanotechnology 2008, DOI:10.1088/09574484/19/01/015102.

36. Han J, Zhang HT, Zhu LM, Branford-White CJ. Electrospun biodegradable nanofiber mats for controlled release of herbal medicine. 3rd Int Conf Bioinform Biomed Eng 978-1-4244-2902-2009 IEEE

37. Agnes Mary A, Giri Dev V.R. Electrospun herbal 80/00405000.2014.951247.

38. DeMario MD, Ratain MJ. Oral chemotherapy: rationale and future directions. J Clin Oncol 1998; 16:2557-2567. 